\title{
Malignant Cranial Nerve Neoplasm
}

National Cancer Institute

\section{Source}

National Cancer Institute. Malignant Cranial Nerve Neoplasm. NCI Thesaurus. Code C3571.

Abnormal malignant growth of the cells that comprise the cranial nerve. 